\title{
OPTIMALISASI PERAN BADAN PENASEHATAN, PEMBINAAN DAN PELESTARIAN PERKAWINAN (BP4) DALAM RANGKA PEMBENTUKAN KELUARGA SAKINAH DI KABUPATEN JEMBER
}

\author{
Wildana Setia Warga Dinata \\ Pengadilan Agama Bawean \\ wildana.setia@gmail.com
}

\begin{abstract}
Abstrak
This research aiming to describe the role of the council of advisory, guidance, and preservation of marriage (BP4) of Puger sub-district in building a harmonious household life. It also means to identify the effectiveness of its role in building the harmonious household. This research uses sequential exploratory design method, which combines the series of research results. Moreover, this research uses descriptive analysis to analyze its qualitative data, while researcher also uses dependent-test analysis in analyzing its quantitative data. The result of research shows that the council of advisory, guidance and preservation of marriage (BP4) of Puger sub-district performed in preventive and curative method. And according to the result of surveys directed to 127 respondents, the role of BP4 is showing a significance fruit in building a harmonious family. The result of statistics shows that $t$ result is bigger than $t$ table $(5,309>1,979)$ in $d f=126$ and $\alpha=0,05$. It means Ho is rejected and $\mathrm{Ha}$ is accepted. It also means that statistically there is difference result before and after the guidance performed by BP4.

Penelitian ini bertujuan untuk mendeskripsikan peran Badan Penasehatan Pembinaan dan Pelestarian Perkawinan (BP4) Kecamatan Puger dalam membentuk Keluarga Sakinah. Serta mengidentifikasi efektifitas peran lembaga ini dalam membentuk Keluarga Sakinah. Metode penelitian yang digunakan dalam penelitian ini adalah termasuk dalam jenis Sequential Exploratory Design atau metode penelitian kombinasi model urutan penemuan. Dengan menggunakan analisis Deskriptif Analitis untuk data Kualitatifnya, sedangkan untuk data Kuantitatifnya penulis menggunakan analisa dependen t-test. Hasil penelitian menunjukkan bahwa pembentukan keluarga sakinah yang dilakukan oleh BP4 Kecamatan Puger dilakukan melalui upaya preventif dan upaya kuratif. Berdasarkan hasil survey yang dilakukan terhadap 127 responden, peran BP4 menunjukkan hasil yang sangat signifikan terhadap pembentukan keluarga sakinah. Hasil penghitungan statistik menunjukkan bahwa thitung lebih besar dari t tabel $(5,309>1,979)$ pada $d f=126$ dan $\alpha=0,05$ berarti Ho ditolak dan Ha diterima. Artinya secara statistik ada perbedaan antara sebelum dan sesudah dilakukan pembinaan keluarga sakinah yang dilakukan oleh BP4.
\end{abstract}

Kata Kunci: BP4, penasehatan, perkawinan, keluarga sakinah 
Perkawinan merupakan pertalian yang sah antara seorang lelaki dan seorang perempuan untuk waktu yang lama. ${ }^{1}$ Sedangkan menurut hukum Islam perkawinan adalah akad yang mitsaqan ghalidzan, untuk menaati perintah Allah dan melaksanakannya merupakan ibadah. ${ }^{2}$ Tidak jauh berbeda dengan definisi di atas, Undang-Undang Nomor 1 Tahun 1974 tentang Perkawinan memberikan gambaran bahwa perkawinan adalah ikatan lahir batin antara seorang pria dengan seorang wanita sebagai suami istri dengan tujuan membentuk keluarga (rumah tangga) yang bahagia dan kekal berdasarkan Ketuhanan Yang Maha Esa. ${ }^{3}$ Sebagai sebuah naluri dasar manusia, menurut Kamal Muchtar perkawinan memiliki beberapa tujuan, antara lain: (1) Supaya umat manusia hidup dalam masyarakat yang teratur dan tentram, baik lahir maupun batin; (2) Supaya kehidupan dalam suatu rumah tangga teratur dan tertib sehingga muncul anak-anak yang saleh, berbaikti kepada kedua orang tua, agama, masyarakat, bangsa dan Negara; (3) Supaya terjalin hubungan yang harmonis antara suami istri, sehingga akan terbentuk ukhuwah yang mendalam dan diridhai oleh Allah SWT. ${ }^{4}$

Idealitas perkawinan sering kali tidak berbanding lurus dengan realitas yang terjadi di masyarakat. Keretakan rumah tangga yang mengakibatkan perceraian terus mengalami peningkatan di berbagai wilayah. Setiap tahun tidak kurang dari 200 ribu perceraian terjadi di Indonesia. Untuk menekan angka perceraian Dirjen Bimas Islam sedang melakukan berbagai upaya di antaranya memperpanjang waktu bimbingan pranikah bagi calon pengantin. Bimas Islam akan merevitalisasi lembaga

${ }^{1}$ R. Subekti, dan R. Djitosudibio, Kitab UndangUndang Hukum Perdata (BW) dengan tambahan UU Pokok Agraria dan UU Perkawinan (Jakarta: Pradnya Paramita, 1994), h. 449.

${ }^{2}$ Departemen Agama RI, Kompilasi Hukum Islam di Indonesia, (Jakarta: Dirjen Pembinaan Kelembagaan Agama Islam, 1992), h. 1

${ }^{3}$ Undang-Undang Nomor 1 Tahun 1974 tentang Perkawinan LN. Tahun 1974 No. 1

${ }^{4}$ Kamal Muchtar, Asas-asas Hukum Islam tentang Perkawinan, (Jakarta: Bulan Bintang, 1993), h. 4 kepenasehatan perkawinan yang sudah ada dan melibatkan perguruan tinggi untuk merealisasikan agenda tersebut. ${ }^{5}$ Salah satu wilayah dengan tingkat perceraian cukup tinggi adalah Kabupaten Jember. Dari jumlah perkara yang ditangani Pengadilan Agama Jember, sebagian besar ada perceraian dan diajukan oleh istri. Grafik perkembangan perceraian yang masuk ke Pengadilan Agama Jember seperti terlihat grafik berikut ${ }^{6}$ :

Gambar 1 Statistik Perkara diterima di Pengadilan Agama Kabupaten Jember tahun 2006 - 2013.

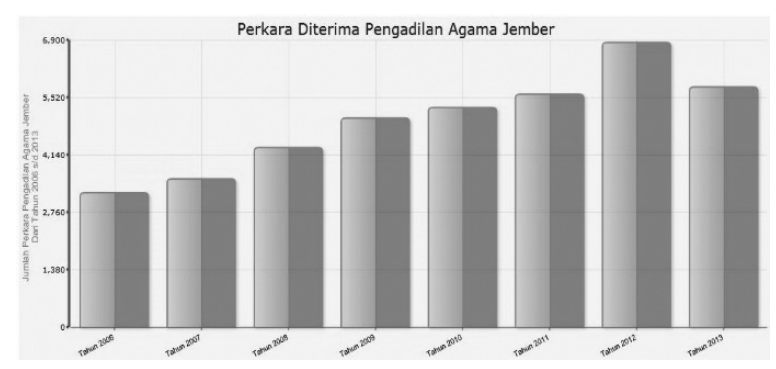

Adapun hal-hal yang mengakibatkan atau menjadi faktor penyebab tejadinya perceraian di Kabupaten Jember dapat dilihat dari tabel dibawah ini:

${ }^{5}$ Edy Supriyatna Sjafei, Mencari Keluarga Sakinah di Tengah Maraknya Perceraian, http://www.antaranews. com/berita/216307/mencari-keluarga-sakinah-ditengah-maraknya-perceraian), diakses tanggal 30 Agustus 2013

${ }^{6}$ Info Perkara Peradilan Agama Indonesia, http:// infoperkara.badilag.net, diakses tanggal 19 Oktober 2013

${ }^{7}$ Penyebab Perceraian di Wilayah Jember, http//www. pajember.net, diakses tanggal 19 September 2013 


\begin{tabular}{|c|l|r|}
\hline No. & Faktor" Penyebab Perceraian & Total \\
\hline 1. & Poligami Tidak Sehat & - Perkara \\
\hline 2. & Krisis Akhlak & - Perkara \\
\hline 3. & Cemburu & 15 Perkara \\
\hline 4. & Kawin Paksa & 9 Perkara \\
\hline 5. & Ekonomi & 126 Perkara \\
\hline 6. & Tidak Ada Tanggung Jawab & 82 Perkara \\
\hline 7. & Kawin Di Bawah Umur & 1 Perkara \\
\hline 8. & Kekejaman Jasmani & 4 Perkara \\
\hline 9. & Kekejaman Mental & - Perkara \\
\hline 10. & Dihukum & - Perkara \\
\hline 11. & Cacat Biologis & 1 Perkara \\
\hline 12. & Politis & - Perkara \\
\hline 13. & Gangguan Pihak Ketiga & 66 Perkara \\
\hline 14. & Tidak Ada Keharmonisan & 139 Perkara \\
\hline 15. & Lain-Lain & - Perkara \\
\hline & Jumlah Total & 443 Perkara \\
\hline
\end{tabular}

Berdasarkan tabel di atas, diketahui bahwa disharmoni menjadi faktor dominan penyebab perceraian. Muncul hipotesis bahwa pendampingan terhadap pasangan suami istri tidak maksimal sehingga muncul berbagai problem rumah tangga dan berakhir dengan perceraian. Dari 31 Kecamatan di Kabupaten Jember, Kecamatan Puger melakukan pencatatan perkawinan dengan jumlah paling banyak yaitu 1276 pasangan suami-istri. Jika tidak dilakukan pembinaan secara maksimal, tidak menutup kemungkinan akan terjadi berbagai problem rumah tangga di wilayah ini. Tidak jauh berbeda dengan wilayah lainnya, di Kecamatan Puger juga terdapat lembaga penasihatan perkawinan atau dikenal dengan nama Badan Penasehatan Pembinaan dan Pelestarian Perkawinan (BP4). Pada era tahun 1960-1970-an lembaga ini mampu mengurangi angka perceraian di seluruh wilayah di Indonesia. Kompleksitas masalah keluarga yang terjadi di masyarakat menuntut BP4 merumuskan strategi baru untuk mengurai berbagai problem rumah tangga. Berdasarkan fenomena di atas, penelitian ini berupaya mendeskripsikan langkah yang dilakukan Badan Penasehatan
Pembinaan dan Pelestarian Perkawinan (BP4) KUA Kecamatan Puger dalam rangka membina Keluarga Sakinah. Kemudian mengidentifikasi efektifitas Badan Penasehatan Pembinaan dan Pelestarian Perkawinan (BP4) KUA Kecamatan Puger dalam membentuk Keluarga Sakinah.

\section{Kajian Teori}

\section{Sejarah Pendirian BP4 di Indonesia}

Badan Penasehatan, Pembinaan, dan Pelestarian Perkawinan disingkat dengan BP4 adalah organisasi profesional yang bersifat sosial keagamaan sebagai mitra Kementerian Agama dan Instansi terkait dalam tugas meningkatkan mutu perkawinan dengan mengembangkan gerakan keluarga sakinah. ${ }^{8}$ Kelahiran BP4 dalam bidang konsultasi perkawinan dan keluarga berawal dari hasil riset Departemen Agama Republik Indonesia yang menunjukkan tingginya angka perceraian di Indonesia pada tahun 1950 sampai dengan tahun1954. Data statistik menunjukkan bahwa angka perceraian mencapai $60-80 \%$ (rata-rata $1300-1400$ kasus perceraian perhari). Kondisi ini mendorong M. Nasaruddin Latif yang menjabat sebagai Kepala Kantor Urusan Agama Kotapraja Jakarta Raya mencetuskan gagasan tentang organisasi penasehatan perkawinan. Besarnya angka perceraian merupakan kondisi darurat bagi bangsa dan negara. Perceraian yang dilakukan secara sewenang-wenang menyebabkan kaum wanita menderita dan membuat anak-anak menjadi terlantar. Perceraian tidak hanya merusak sendi-sendi kehidupan kemasyarakatan, bahkan juga akan meruntuhkan akhlak dan kepribadian serta meluasnya kemaksiatan. ${ }^{9}$ Atas persetujuan Departemen Agama, pada tanggal 4 April 1954 dibentuklah Seksi Penasihat Perkawinan (SPP) di kantor-kantor Urusan Agama Kotapraja Jakarta Raya. Sejak tanggal

${ }^{8}$ Keputusan Musyawarah Nasional Badan Penasihatan, Pembinaan dan Pelestarian Perkawinan (BP4) Ke XV Tahun 2014 Nomor 260/2-P/BP4/ VIII/2014 tentang Anggaran Dasar Badan Penasihatan, Pembinaan dan Pelestarian Perkawinan (BP4) Tahun 2014

${ }^{9}$ H.S.M. Nasaruddin Latif, Biografi dan Pemikiran (Jakarta:GIP, 1996), h. 7 
20 Juli 1954, Departemen Agama menjalankan kebijakan bahwa setiap orang yang akan bercerai dipersilahkan mendatangi Seksi Penasihat Perkawinan setempat untuk mendapatkan bimbingan. ${ }^{10}$

Pada tanggal 3 Oktober 1954, Abdur Rauf Hamidy yang menjabat sebagai Kepala Jawatan Urusan Agama Provinsi Jawa Barat juga mendirikan Badan Penasihat Perkawinan dan Penyelesaian Perkawinan (BP4). Kesuksesan lembaga yang digagas oleh Nasaruddin Latif menarik minat organisasi-organisasi wanita yang tergabung dalam KOWANI. Pada tahun 1956, sebanyak 21 organisasi perempuan melakukan konggres dan menyepakati terbentuknya Panitia Penasehatan Perkawinan dan Penyelesaian Perkawinan(P5). Organisasi ini diketuai oleh SR Poedjotomo dan M. Nasaruddin Latif sebagai penasihat. Wadah baru ini berstatus sebagai organisasi kemasyarakatan yang bergerak di bidang usaha mengurangi perceraian dan mempertinggi nilai perkawinan. Gerak langkah P5 kemudian meluas sampai ke daerah-daerah di luar Jakarta, seperti Malang, Surabaya Kediri, Lampung, dan Kalimantan..$^{11}$ Gerakan serupa meluas ke berbagai provinsi. Pada tahun 1958, Alfiyah Muhadi, Anwar Musaddad dan Samawi memprakarsai lembaga penasehatan perkawinan di tiga wilayah yang berbeda, yaitu di Yogyakarta, Jawa Timur dan Jawa Tengah. Lembaga ini diberi nama Badan Kesejahteraan Rumah Tangga (BKRT). ${ }^{12}$

Pada tanggal 3 Januari 1960, pengurus lembaga penasehatan perkawinan dan penyelesaian perceraian se-Jawa melakukan pertemuan. Dalam pertemuan ini muncul gagasan peleburan organisasi-organisasi yang bersifat lokal menjadi badan nasional yang diberi nama Badan Penasehatan Perkawinan dan Penyelesaian Perceraian atau disingkat menjadi BP4. Berdasarkan kesepakatan ini, dalam Konferensi Dinas Departemen Agama ke-VII pada tanggal 25-30 Januari 1960, di Cipayung, Bogor, organisasi BP4 dikukuhkan melalui

\footnotetext{
${ }^{10}$ H.S.M. Nasaruddin Latif, Biografi...., h. 8

${ }^{11}$ H.S.M. Nasaruddin Latif, Biografi..., h. 8

${ }^{12}$ (Cari Situs BP4 Jateng)
}

Surat Keputusan Menteri Agama RI Nomor 85 Tahun 1961. Keputusan ini menjadikan BP4 sebagai organisasi resmi nasional yang berpusat di Jakarta dan memiliki cabang di seluruh wilayah Indonesia. ${ }^{13}$ Kantor pusat BP4 terletak di Masjid Istiqlal Ruang 66 Jl. Taman Wijaya Kusumah Jakarta Pusat. Pasca lahirnya Undang-Undang Nomor 1 Tahun 1974 tentang Perkawinan, BP4 tidak lagi bertugas menyelesaikan perceraian dan hanya tugasnya hanya semata-mata memberikan penasehatan. Dalam rangka merespon Undang-Undang ini, berdasarkan Keputusan Menteri Nomor 30 tahun 1977, institusi ini berubah nama menjadi Badan Penasihat Perkawinan, Perselisihan dan Perceraian (BP4) dan dinyatakan sebagai satusatunya badan semi penunjang sebagian tugas Departemen Agama di bidang penasehatan perkawinan, perselisihan rumah tangga dan perceraian. Seiring dengan perkembangan zaman, berdasarkan Keputusan Menteri Agama Republik Indonesia No. 417 Tahun 2004 lembaga ini kembali berubah nama menjadi "Badan Penasehatan, Pembinaan dan Pelestarian Perkawinan (BP4) Pusat".

Pada Musyawarah Nasional BP4ke-14 Tahun 2009, BP4 melakukan transformasi kelembagaan dari organisasi semi resmi menjadi organisasi yang mandiri dan professional. Perubahan kelembagaan ini tidak merubah tugas pokok BP4. Lembaga ini tetap menjadi mitra Kementerian Agama di bidang Penasehat Perkawinan, Perselisihan Rumah Tangga. Perubahan kelembagaan ini diaturberdasarkan:(1) Anggaran Dasar termuat dalam Akta Nomor 08 tanggal 22 Maret 2010 dan Akta Nomor 08 tanggal 29 Juni 2010 dibuat oleh Notaris Saifuddin Arief, SH., MH; (2) Keputusan Menteri Hukum dan HAM RI Nomor : AHU-100.AH.01.06 Tahun 2010 tentang Pengesahan Akta Pendirian Perkumpulan Badan Penasehatan, Pembinaan dan Pelestarian Perkawinan (BP4) tertanggal 21 Juli 2010. Berbagai problem perkawinan dan keluarga pada kurun waktu 10 tahun terakhir menjadi semakin kompleks. Misalnya, angka perceraian yang tinggi, kekerasan dalam rumah

${ }^{13}$ H.S.M. Nasaruddin Latif, Biografi..., h. 8 
tangga, perkawinan sirri, perkawinan mut'ah, poligami tidak sehat, dan perkawinan di bawah umur. Komplesitas problem rumah tangga yang dihadapi pasangan suami-istri, menuntut BP4 untuk menata kembali peran dan fungsinya agar mampu mensesuaikan dengan kondisi dan perkembangan masyarakat. Visi BP4 ke depan tidak hanya berperan dan berfungsi sebagai lembaga penasihatan perkawinan tetapi juga sebagai lembaga pendidikan, mediator dan advokasi perkawinan. ${ }^{14}$

\section{Visi dan Misi BP4}

Visi BP4 adalah terwujudnya keluarga sakinah, mawaddah wa rahmah sebagai basis kehidupan masyarakat dan bangsa yang sejahtera secara fisik materil dan mental spiritual. Sedangkan Misi BP4 adalah: (1) Meningkatkan kualitas konsultasi perkawinan, mediasi, dan advokasi; (2) Meningkatkan pelayanan terhadap keluarga yang bermasalah melalui kegiatan konseling, mediasi dan advokasi; (3) Menguatkan kapasitas kelembagaan dan SDM BP4 dalam rangka mengoptimalkan program dan pencapaian tujuan.

\section{Tujuan dan Tugas Pokok BP4}

Secara historis, pendirian BP4 tidak terlepas dari upaya pemerintah mengurangi tingginya angka perceraian. Pada era 1960-1990-an peran BP4 cukup signifikan dalam mengurangi angkat perceraian di Indonesia. Riset Departemen Agama pada tahun 1950-an menunjukkan bahwa angka perceraian secara nasional mencapai separoh dari jumlah perkawinan yang terjadi di masyarakat. Namun, sejak tahun 1970-an angka perceraian mengalami penurunan. Selain faktor berlakunya Undang-Undang Nomor 1 Tahun 1974 tentang Perkawinan yang mempersulit perceraian, penurunan jumlah perceraian tidak terlepas dari peran BP4. Sebelum mendaftarkan perkara perceraian di pengadilan agama, pasangan suami-istri harus mendapatkan bimbingan dan penaseharan di BP4 terlebih dahulu. Melalui upaya ini sejak tahun 1990-an, angka perceraian terus bertahan

\footnotetext{
${ }^{14}$ profil Bp4 www.bp4pusat.or.id.diakses tgl 2 November 2015
}

sekitar 6-7\% dari angka perkawinan di seluruh Indonesia. ${ }^{15}$ Tujuan umum pendirian BP4 juga dapat ditemukan dalam konsideran Anggaran Dasar BP4. Di era kontemporer ini peran BP4 sangat diperlukan untuk menciptakan iklim yang kondusif dalam memberikan motivasi kepada para keluarga untuk menanamkan, melaksanakan dan mengembangkan nilai-nilai ajaran agama dan akhlaqul karimah. Pendirian BP4 juga sebagai upaya meningkatkan kualitas perkawinan menurut ajaran Islam diperlukan bimbingan dan penasihatan perkawinan secara terus-menerus dan konsisten agar dapat mewujudkan rumahtangga/keluarga yang sakinah mawaddah warahmah.

Dalam Pasal 5 Anggaran Dasar BP4 yang menyebutkan bahwa tujuan BP4 adalah mempertinggi mutu perkawinan guna terwujudnya rumah tangga atau keluarga yang sakinah menurut ajaran Islam untuk mencapai masyarakat dan bangsa Indonesia yang maju, mandiri, dan sejahtera baik material maupun spiritual dengan: (1) Meningkatkan kualitas perkawinan dan kehidupan keluarga yang sakinah mawaddah warahmah; (2) Menurunkan angka perceraian dengan meningkatkan pelayanan terhadap keluarga yang bermasalah melalui kegiatan konseling, mediasi dan advokasi; (3) Menguatkan kapasitas kelembagaan dan SDM $\mathrm{BP} 4$ dalam rangka mengoptimalkan program dan pencapaian tujuan; (4) Memberikan penyuluhan tentang peraturan perundangundangan yang berkaitan dengan keluarga; (5) Mengembangkan jaringan kemitraan dengan intansi/ lembaga yang memiliki misi dan tujuan yang sama. ${ }^{16}$

Untuk mewujudkan tujuan tersebut BP4 melakukan berbagai upaya sebagai berikut: (1) Memberikan bimbingan, penyuluhan, penasihatan, dan konsultasi/konseling, mengenai

${ }^{15}$ Zubaedi, "Mengkritisi Peran BP4 dalam Melestarikan Lembaga Perkawinan", Jurnal Penelitian Keislaman, Vol. 6, No. 2, (Juni 2010), h. 470

${ }^{16}$ Keputusan Musyawarah Nasional Badan Penasihatan Pembinaan dan Pelestarian Perkawinan (BP4) XV Tahun 2014 Nomor : 260/2-P/BP4/VIII/2014 tentang Anggaran Dasar dan Anggaran Rumah Tangga Badan Penasihatan, Pembinaan dan Pelestarian Perkawinan Tahun 2014 
nikah, talak, cerai, rujuk kepada masyarakat baik perorangan maupun kelompok, secara langsung atau melalui media massa dan media elektronik; (2) Memberikan bimbingan tentang peraturan perundang-undangan yang berkaitan dengan keluarga; (3) Memberikan bantuan mediasi kepada para pihak yang berperkara di pengadilan agama; (4)Memberikan bantuan advokasi dalam mengatasi masalah perkawinan, keluarga dan perselisihan rumah tangga di peradilan agama; (5) Mengurangi angka perselisihan, perceraian, poligami yang tidak bertanggung jawab, pernikahan di bawah umur dan pernikahan tidak tercatat; (6) Bekerjasama dengan instansi, lembaga dan organisasi yang memiliki kesamaan tujuan baik di dalam maupun di luar negeri; (7) Menerbitkan dan menyebarluaskan majalah perkawinan dan keluarga, buku, brosur, media massa dan media elektronik yang dianggap perlu; (8) Menyelenggarakan kursus pra nikah, penataran/pelatihan, diskusi, seminar dan kegiatan-kegiatan sejenis-yang berkaitan dengan perkawinan dan keluarga; (9) Menyelenggarakan pendidikan keluarga untuk peningkatkan penghayatan dan pengamalan nilai-nilai keimanan, ketaqwaan dan akhlaqul karimah dalam rangka membina keluarga sakinah; (10) Berperan aktif dalam kegiatan lintas sektoral yang bertujuan membina keluarga sakinah; (11) Meningkatkan upaya pemberdayaan ekonomi keluarga dan kewirausahaan; dan (12) Upaya dan usaha lain yang dipandang bermanfaat untuk kepentingan organisasi serta bagi kebahagiaan dan kesejahteraan keluarga.

\section{Susunan Organisasi dan Pengurus BP4}

Berdasarkan Pasal 7 Anggaran Dasar BP4 diketahui bahwa organisasi BP4 disusun sesuai dengan jenjang administrasi pemerintah mulai dari tingkat Pusat, Provinsi, Kabupaten/Kota, dan Kecamatan. Untuk mewujudkan visi, misi, dan tugas pokoknya organisasi BP4 mempunyai bidang-bidang sesuai kebutuhan meliputi: (a) Bidang Konsultasi/Konseling, Mediasi, Advokasi dan Penasehatan Perkawinan dan Keluarga; (b) Bidang Pendidikan, Pelatihan, dan Kursus; (c) Bidang Kemitraan, Kerjasama dan Wirausaha; dan (d) Bidang Humas dan Publikasi,dokumentasi. Selain itu, untuk menunjang tugasnya BP4 Pusat sampai Tingkat Kecamatan memiliki tenaga Konselor dan Penasihat Perkawinan dan Keluarga. Sedangkan susunan pengurus BP4 diatur berdasarkan Pasal 8 Anggaran Dasarnya. Melalui pasal tersebut diketahui bahwa susunan organisasi BP4 yaitu: Pembina BP4 tingkat Pusat terdiri dari: Ketua Mahkamah Agung, Menteri Agama Rl, Menteri dan Kepala Lembaga terkait; Pembina BP4 tingkat Provinsi adalah Gubernur; Pembina BP4 di tingkat Kabupaten/Kota adalah Bupati/ Walikota; Pembina di tingkat Kecamatan adalah Camat. Kemudian Dewan Pertimbangan BP4 terdiri dari unsur pejabat Kementerian Agama dan Peradilan Agama, institusi terkait, ulama, tokoh organisasi Islam dan cendikiawan. Tim Ahli BP4 terdiri dari tokoh dan para ahli yang berpengalaman dalam pelaksanaan program pembinaan dan penguatan perkawinan dan keluarga yang sakinah yang secara operasional memberikan dukungan kepada pengurus BP4 dalam pelaksanaan program, terutama dalam bentuk pemikiran, ide dan gagasan. Pengurus BP4 terdiri dari ketua umum dan wakil ketua umum, ketua-ketua, sekretaris umum, wakil sekretaris umum, bendahara, wakil bendahara, serta bidang-bidang. Pengurus BP4 sebagaimana dimaksud ayat (4) adalah pribadi muslim dan muslimah dari instansi pemerintah, ormas Islam, tenaga professional, serta tenaga ahli dari berbagai disiplin ilmu terkait fungsi BP4. Masa bakti pengurus di semua tingkat adalah 5 tahun dan dapat dipilih kembali, kecuali ketua umum hanya dapat dipilih satu periode berikutnya.

\section{Metode Penelitian}

Adapun jenis penelitian kali ini adalah termasuk dalam jenis Sequential Exploratory Design atau metode penelitian kombinasi model urutan penemuan. ${ }^{17}$ Yaitu metode

\footnotetext{
${ }^{17}$ Jonathan Sarwono, Mixed Methods Cara Menggabungkan Riset Kuantitatif dan Riset Kualitatif Secara Benar, (Jakarta: PT Elex Media Komputindo, 2011), h. 5.
} 
penelitian kombinasi yang menggabungkan metode penelitian kualitatif dan kuantitatif secara beruntun, dimana pada tahap pertama penelitian menggunakan metode kualitatif dan tahap kedua menggunakan kuantitatif. Metode kualitatif berfungsi untuk menemukan hipotesis pada kasus tertentu atau sampel terbatas, dan metode kuantitatif berfungsi untuk menguji hipotesis pada populasi lebih luas. Metode ini berguna untuk menemukan hipotesis dan sekaligus membuktikan validitas eksternal hipotesis tersebut. Adapun lokasi penelitian yang peneliti lakukan adalah di Kantor Urusan Agama Kecamatan Puger Kabupaten Jember Jl. Gumukmas Telp. 0336 721237 Puger Jember Jawa Timur Kodepos 68164. Jenis data yang digunakan yaitu data primer, diperoleh dari hasil wawancara tidak terstuktur ${ }^{18}$ dengan Kepala Badan Penesahatan, Pembinaan dan Pelestarian Perkawinan (BP4) Kecamatan Puger dan/atau Pejabat yang diberi wewenang khusus menangani Penasehatan. Untuk menilai efektifitas penasehatan BP4 peneliti melibatkan 127 orang responden yang dipilih dengan menggunakan teknik accidental sampling yaitu mengambil kasus yang kebetulan ada atau tersedia di suatu tempat sesuai konteks penelitian, $\cdot{ }^{19}$ Karena dalam penelitian ini menggunakan dua metode sekaligus maka analisis data kualitatif menggunakan Deskriptif Analitis sedangkan untuk data kuantitatifnya menggunakan uji statistik dependen $t$-test dengan bantuan software SPSS versi 2.0.

\section{Hasil dan Pembahasan}

\section{Peran BP4 Kecamatan Puger dalam Membentuk Keluarga Sakinah}

BP4 Kecamatan Puger Jember memiliki peran dan tugas mewujudkan keluarga yang sakinah, mawaddah, dan warahmah sebagaimana amanat Anggaran Dasar BP4 Nasional. Peran BP4 Kecamatan Puger sebagai organisasi mitra pemerintah tergolong pada dua upaya, yaitu: Pertama, Upaya Preventif, yaitu upaya yang

\footnotetext{
${ }^{18} \mathrm{Abu}$ Achmadi dan Cholid Narkubo, Metode Penelitian (Jakarta : PT. Bumi Aksara, 2005), h. 85.

${ }^{19}$ Sugiono, Memahami Penelitian Kualitatif, (Bandung: CV Alfabeta, 2008), h. 300
}

dilakukan BP4 sebelum adanya perkawinan. Upaya ini sangat besar manfaatnya karena supaya dalam menjalankan kehidupan setelah perkawinan pasangan suami istri tersebut sudah dibekali dengan pengetahuan tentang perkawinan. BP4 Kecamatan Puger dalam mewujudkan upaya Preventifnya berupa: a) Pemberian nasihat dan penyuluhan kepada calon pengantin yang akan membentuk rumah tangga. Tahap pemberian penasihatan dan penyuluhan yang diberikan pada pasangan yang akan membentuk rumah tangga, dimaksudkan agar mereka memahami secara benar peran masingmasing dalam kehidupan rumah tangganya guna menciptakan kebahagiaan hidup rumah tangganya. Pemberian nasihat dan penyuluhan itu diadakan melalui penataran bimbingan pranikah bagi calon pengantin dalam tenggang waktu 10 hari dari kehendak nikah, atau disebut dengan nama "SUSCATIN" (Kursus Calon Pengantin) yang dilakukan oleh Ketua BP4 atau bagian Penasehatan BP4 Kecamatan Puger; b) Memberikan informasi bahwa BP4 Kecamatan Puger merupakan lembaga yang memberi fasilitas konsultasi rumah tangga yang bisa dimanfaatkan oleh semua masyarakat di Wilayah Kerja Kecamatan Puger. Sehingga nantinya apabila ada permasalahan dalam rumah tangga calon pengantin dapat mengkonsultasikannya kepada BP4 Kecamatan Puger; c) Memberikan ceramah-ceramah tentang perkawinan, hikmah perkawinan, dan tentang berumah tangga yang sesuai dengan syari'at dan tuntunan agama islam pada acara Walimatul Ursy. Agar hubungan perkawinan tetap terpelihara dan hidup dengan suasana yang harmonis sakinah mawaddah warrrahmah. Peningkatan terhadap kualitas dan nilai rumah tangga diharapkan dapat menekan terjadinya perceraian. Adanya bimbingan yang berkesinambungan dari petugas $\mathrm{BP} 4$ diharapkan mampu mewujudkan rumah tangga yang sakinah, mawaddah, dan warrahmah.

Kedua, Upaya Kuratif, yaitu kegiatan yang dilakukan oleh BP4 Kecamatan Puger berupa pemberian nasihat terhadap pasangan suami istri yang sedang mengalami perselisihan dan berupaya mencari jalan keluar terbaik atas 
masalah yang mereka hadapi. Pendekatan yang digunakan oleh BP4 bukan pendekatan yuridis, melainkan lebih menekankan pada aspek psikologis dan keagamaan. Pelaksanaan upaya kuratif akan disesuaikan dengan keadaan pasangan suami-istri. Meskipun deikian, banyak pasangan yang enggan datang ke BP4 dan langsung mendaftarkan perkara mereka di Pengadilan Agama Jember.

Pelaksanaan program yang preventif maupun kuratif dalam rangka memperkuat institusi perkawinan, BP4 Kecamatan Puger perlu disusun dan direncanakan sebaik mungkin. Setidaknya dalam penyusunan program, pengurus BP4 memperhatikan faktor internal sebagai berikut: (a) Pendidikan suami-istri, secara umum dipahami bahwa pada umumnya makin tinggi pendidikan seseorang makin mudah pula menerima informasi. Selain itu, jenjang pendidikan juga mempengaruhi konten pembinaan yang diberikan kepada pasangan suami istri; (b) Pekerjaan suami-istri, pembinaan yang dilakukan harus mempertimbangkan jenis pekerjaan, pendapatan, tempat bekerja, dan orang yang terlibat dalam aktivitas ekonomi keluarga. Keluarga dengan salah satu pihak saja yang bekerja dan dua belah pihak sama-sama berkerja memiliki kondisi yang berbeda; (c) Usia suami-istri, secara umum usia seseorang akan membentuk pengalaman dan kematangan jiwa. Dua aspek ini berpengaruh terhadap konten yang akan diberikan kepada pasangan suami-istri.

Selain itu, pengurus BP4 juga diharapkan memperhatikan Faktor Eksternal yang turut mempengaruhi terlaksananya program pembinaan keluarga di wilayah Kecamatan Puger. Faktor tersebut antara lain: (a) Faktor lingkungan, yaitu kondisi yang ada di sekitar manusia dan pengaruhnya yang dapat mempengaruhi perkembangan dan perilaku orag atau kelompok. Pendekatan yang digunakan terhadap masyarakat pedesaan (rural) akan berbeda dengan masyarakat kota (urban). Begitu pula masyarakat yang tinggal di wilayah pesisir pantai akan memiliki karakteristik yang berbeda dengan masyarakat pegunungan; (b) Faktor Sosial budaya, yaitu seperangkat tradisi yang ada dalam masyarakat, dipegang teguh, serta diwariskan secara turun temurun dapat mempengaruhi sikap dalam menerima informasi. Misalnya, individu yang dibesarkan dalam lingkungan pondok pesantren akan memiliki ketaatan tinggi terhadap kiai, ustad, habib, atau ulama setempat. ${ }^{20}$ Melalui proses perencanaan yang tepat diharapkan pasangan suami-istri yang mengikuti program BP4 baik yang bersifat preventif dan kuratif dapat memiliki pengetahuan tentang konsep keluarga sakinah. Keluaran program ini adalah keluarga dengan kriteria-kriteria sebagai berikut: 1) Keluarga dibina atas perkawinan yang sah; 2 ) Keluarga mampu memenuhi hajat hidup baik secara materil maupun spiritual dengan layak; 3) Keluarga mampu menciptakan suasana cinta kasih dan kasih sayang antara sesama anggota;4) Keluarga mampu menanamkan dan mengamalkan nilai-nilai keimanan, ketakwaan, amal saleh dan akhlaqul karimah; 5) Keluarga mampu mendidik anak dan remaja minimal sampai dengan sekolah menengah umum; 6) Kehidupan sosial ekonomi keluarga mampu mencapai tingkat yang memadai sesuai dengan ukuran masyarakat yang maju dan mandiri.

\section{Efektifitas Peran BP4 KUA Kecamatan Puger dalam Pembinaan Keluarga Sakinah}

Data yang akan dipaparkan dalam bagian ini adalah merupakan data kuantitatif dimana pengambilan data yang dilakukan adalah dengan pemberian Kuisoner berupa Pre-Test (Sebelum dilakukan intervensi) dan Post-Test (Sesudah dilakukan intervensi). Adapun penyajian data yang akan dipaparkan pada sub ini yaitu: Data Umum dan Data Khusus. Data umum adalah data karakteristik responden, yang didalamnya terdapat: Usia, Tingkat pendidikan, dan Pekerjaan. Sedangkan data khusus adalah pemaparan data meliputi: Hasil Pre-Test dan Post-Test Peserta Pembinaan Keluarga Sakinah oleh Badan Penasehatan, Pembinaan dan Pelestarian Perkawinan (BP4) Kecamatan Puger Kabupaten Jember.

${ }^{20}$ Wawan Dewi, Teori dan Pengukuran Pengetahuan, Sikap, dan Perilaku Manusia, (Yogyakarta: Nuha Medika, 2010), h. 23 
Diagram 1:Persentase Rentang Usia Responden Peserta Pembinaan Keluarga Sakinah oleh Badan Penasehatan, Pembinaan dan Pelestarian Perkawinan (BP4) di Kantor Urusan Agama (KUA) Kecamatan Puger Kabupaten Jember Oktober - November 2013.

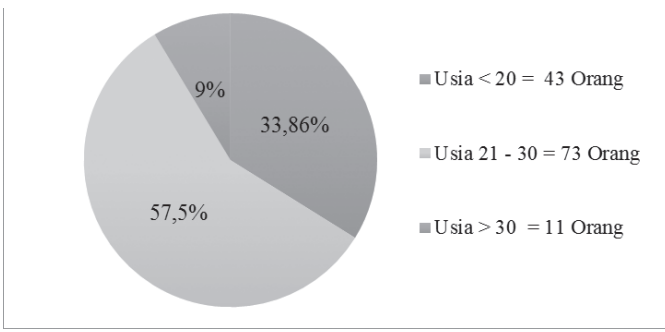

Diagram 2: Persentase Jenjang Pendidikan Responden Peserta Pembinaan Keluarga Sakinah oleh Badan Penasehatan, Pembinaan dan Pelestarian Perkawinan (BP4) di Kantor Urusan Agama (KUA) Kecamatan Puger Kabupaten Jember Oktober - November 2013.

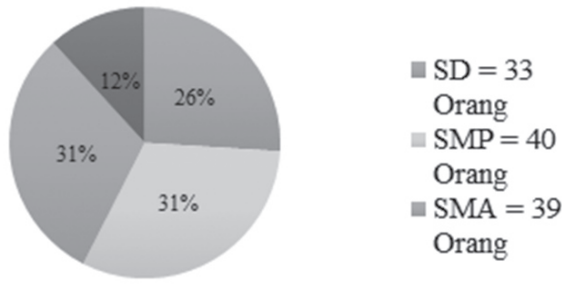

Diagram 3: Persentase Jenis Pekerjaan Responden Peserta Pembinaan Keluarga Sakinah oleh Badan Penasehatan, Pembinaan dan Pelestarian Perkawinan (BP4) di Kantor Urusan Agama (KUA) Kecamatan Puger Kabupaten Jember Oktober - November 2013.

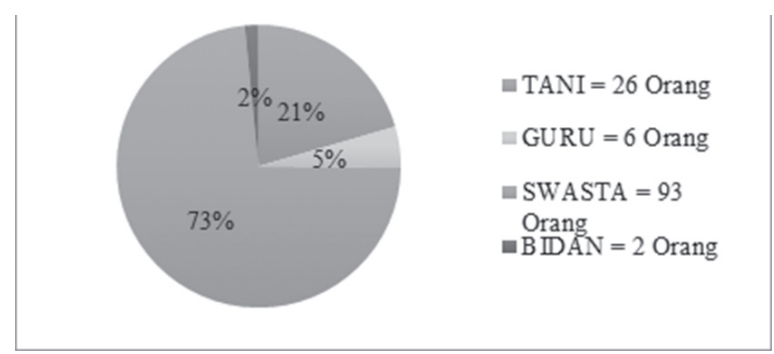

Berdasarkan hasil penelitian tentang Efektifitas Peran Badan Penasehatan, Pembinaan, dan Pelestarian Perkawinan (BP4) dalam membentuk keluarga sakinah di Kantor Urusan Agama (KUA) Kecamatan Puger menunjukkan hasil rata-rata nilai Kuisoner untuk Pre-Test adalah 82,46 dan untuk rata-rata nilai Post-Test adalah 88,03 . Hal ini dapat dilihat dari hasil perhitungan menggunakan software SPSS v. 20 adalah sebagai berikut:

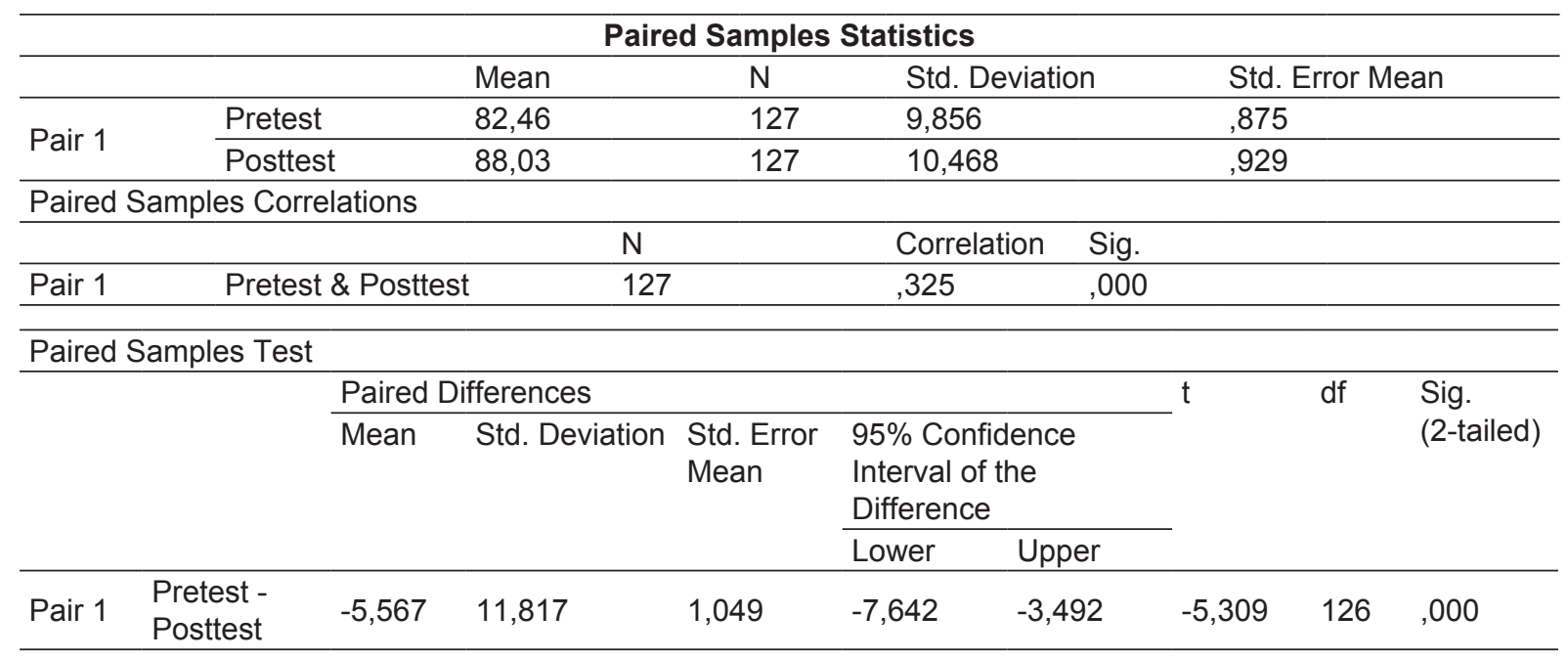


Dari hasil tersebut maka dapat disimpulkan bahwa Efektifitas Peran Badan Penasehatan, Pembinaan, dan Pelestarian Perkawinan (BP4) dari 127 responden menunjukkan hasil yang sangat signifikan antara sebelum dan sesudah intervensi yang dilakukan oleh BP4 Kecamatan Puger dengan memberikan pemahaman tentang pengetahuan keluarga sakinah yaitu thitung lebih besar dari $t$ tabel $(5,309>1,979)$ pada $d f=126$ dan $\alpha=0,05$ berarti Ho ditolak dan Ha diterima. Artinya secara statistik ada perbedaan antara sebelum dan sesudah dilakukan pembinaan keluarga sakinah yang dilakukan oleh di Kantor Urusan Agama (KUA) Kecamatan Puger Kabupaten Jember pada bulan Oktober - November 2013.

Dari hasil penelitian diatas ada beberapa hal yang mempengaruhi keberhasilan intervensi yang dilakukan oleh Badan Penasehatan, Pembinaan, dan Pelstarian Perkawinan (BP4) Kecamatan Puger, yaitu dari 127 responden mayoritas jenjang pendidikan terakhir responden adalah lulusan SMP yaitu sebanyak 40 Orang (31 \%) dan SMA sebanyak 39 Orang (31\%), dan sisanya adalah yang berpendidikan SD dan Perguruan Tinggi. Ini jelas salah satu faktor dominan yang mempengaruhi mudahnya menerima informasi yang diberikan dalam pembinaan keluarga sakinah yang dilakukan oleh BP4 Kecamatan Puger, hal ini juga didukung oleh teori yang dikemukakan oleh Wawan Dewi dimana pendidikan dapat mempengaruhi perilaku seseorang akan pola hidup terutama dalam memotivasi untuk berperan serta dalam pembangunan pada umumnya makin tinggi pendidikan seseorang makin mudah menerima informasi. Selain faktor pendidikan yang mempengaruhi keberhasilan intervensi yang dilakukan oleh Badan Penasehatan, Pembinaan, dan Pelstarian Perkawinan (BP4) Kecamatan Puger adalah faktor usia dari 127 responden mayoritas berusia 20-30 tahun adalah sejumlah 73 orang (57,5\%). Pada rentang usia tersebut seseorang disebut ada pada masa produktif, dimana pada usia ini masih mudah menerima informasi yang diberikan kepadanya. Hal ini juga didukung oleh teori Wawan Dewi yang menyatakan bahwa seseorang yang lebih dewasa lebih dipercaya daripada orang yang belum tinggi kedewasaannya. Hal ini akan membentuk pengalaman dan kematangan jiwa. ${ }^{21}$

\section{Kesimpulan}

Peran Badan Penasehatan, Pembinaan dan Pelestarian Perkawinan (BP4) Kecamatan Puger dalam mekanisme pembentukan keluarga sakinah yang dilakukan oleh Badan Penasehatan, Pembinaan dan Pelestarian Perkawinan (BP4) menggunakan beberapa upaya yaitu Upaya Preventif dan Upaya Kuratif. Upaya Preventif dilakukan ketika pasangan tersebut belum menikah. Sedangkan Upaya Kuratif dilakukan ketika pasangan tersebut telah melangsungkan pernikahan. Upayaini merupakan pengembangan dari yang diamanatkan dalam Surat Keputusan Menteri Agama RI Nomor 18 Tahun 1975 yang kemudian diperbaharui dengan Surat Keputusan Menteri Agama RI Nomor 43 Tahun 1981.

Efektifitas Peran Badan Penasehatan, Pembinaan, dan Pelestarian Perkawinan (BP4) dari 127 responden menunjukkan hasil yang sangat signifikan antara sebelum dan sesudah intervensi yang dilakukan oleh BP4 Kecamatan Puger dengan memberikan pemahaman tentang pengetahuan keluarga sakinah yaitu t hitung lebih besar dari t tabel $(5,309>1,979)$ pada $\mathrm{df}=126$ dan $\alpha=0,05$ berarti Ho ditolak dan Ha diterima. Artinya secara statistik ada perbedaan antara sebelum dan sesudah dilakukan pembinaan keluarga sakinah yang dilakukan oleh Badan Penasehatan, Pembinaan, dan Pelestarian Perkawinan (BP4) di Kantor Urusan Agama (KUA) Kecamatan Puger Kabupaten Jember.

\section{Saran}

Secara teoritis penelitian ini diharapkan berguna bagi khazanah keilmuan khususnya untuk Jurusan Hukum Keluarga dan kalangan civitas akademika yang memfokuskan dirinya pada pemahaman terhadap konsep pembentukan keluarga sakinah dan yang ingin melakukan

\footnotetext{
${ }^{21}$ Wawan Dewi, Teori..., h. 23
} 
penelitan lebih lanjut mengenai topik yang penulis angkat. Penelitian ini juga diharapkan dapat digunakan sebagai refrensi tambahan dalam memahami bagaimana peran yang dilakukan oleh Badan Penasehatan Pembinaan dan Pelestarian Perkawinan (BP4) mulai dari lingkup Nasional, Provinsi, Kabupaten/Kota, sampai lingkup Kecamatan dalam upaya pembentukan keluarga sakinah.

Secara praktis penelitian ini diharapkan memberikan pemahaman atau setidaknya dapat digunakan sebagai bahan pertimbangan oleh lembaga yang concern terhadap urusan pembinaan keluarga sakinah, khususnya di wilayah-wilayah kerja Badan Penasehatan, Pembinaan dan Pelstarian Perkawinan (BP4) disetiap kecamatan di seluruh Indonesia. Karena pada dasarnya masyarakat Puger

\section{DAFTAR PUSTAKA}

Subekti, R. dan R. Djitosudibio, Kitab UndangUndang Hukum Perdata (BW) dengan tambahan UU Pokok Agraria dan UU Perkawinan. Jakarta: Pradnya Paramita. 1994

Departemen Agama RI. Kompilasi Hukum Islam di Indonesia. Jakarta: Dirjen Pembinaan Kelembagaan Agama Islam. 1992

Undang-Undang Nomor 1 Tahun 1974 tentang Perkawinan LN. Tahun 1974 Nomor 1

Muchtar, Kamal. Asas-asas Hukum Islam tentang Perkawinan. Jakarta: Bulan Bintang. 1993

Sjafei, Edy Supriyatna. Mencari Keluarga Sakinah di Tengah Maraknya Perceraian, http:// www.antaranews.com/berita/216307/ mencari-keluarga-sakinah-di-tengahmaraknya-perceraian), diakses tanggal 30 Agustus 2013

Info Perkara Peradilan Agama Indonesia, http:// infoperkara.badilag.net, diakses tanggal 19 Oktober 2013

Penyebab Perceraian di Wilayah Jember, http// www.pajember.net, diakses tanggal 19 September 2013 mengetahui langkah awal yang harus ditempuh ketika terjadi permasalahan dalam keluarga, dan tidak langsung mengajukan gugatannya ke Pengadilan Agama. Hal ini dimungkinkan ada beberapa faktor yang mempengaruhi, dan ini merupakan bahan untuk penelitian selanjutnya. Bimbingan mengenai pembekalan calon pengantin ini juga sudah dilakukan di pemerintahan Malaysia, dimana sertifikat kursus calon pengantin diwajibkan kepada setiap calon pasangan pengantin yang hendak melangsungkan perkawinan. Hal ini tentunya harus dijadikan sebagai bahan pertimbangan oleh pemerintah guna untuk menekan angka perceraian yang ada di Indonesia yang tergolong masih tinggi, tentunya dengan mengoptimalkan kembali lembaga atau badan yang telah lama dibentuk oleh pemerintah yaitu BP4.

Keputusan Musyawarah Nasional Badan Penasihatan, Pembinaan dan Pelestarian Perkawinan (BP4) Ke XV Tahun 2014 Nomor 260/2-P/BP4/VIII/2014 tentang Anggaran Dasar Badan Penasihatan, Pembinaan dan Pelestarian Perkawinan (BP4) Tahun 2014

Latif, H.S.M. Nasaruddin. Biografi dan Pemikiran. Jakarta:GIP. 1996

Zubaedi. Mengkritisi Peran BP4 dalam Melestarikan Lembaga Perkawinan. Jurnal Penelitian Keislaman. 2. 2010.

Sarwono, Jonathan. Mixed Methods Cara Menggabungkan Riset Kuantitatif dan Riset Kualitatif Secara Benar. Jakarta: PT Elex Media Komputindo. 2011

Achmadi, Abu dan Cholid Narkubo. Metode Penelitian. Jakarta : PT. Bumi Aksara. 2005

Sugiono. Memahami Penelitian Kualitatif. Bandung: CV Alfabeta. 2008

Dewi, Wawan. Teori dan Pengukuran Pengetahuan, Sikap, dan Perilaku Manusia. Yogyakarta: Nuha Medika. 2010 